\title{
SOCIAL ENTREPRENEURSHIP IN RURAL AREAS AS ILLUSTRATED BY SOCIAL COOPERATIVES IN POLAND'S MASOVIAN VOIVODESHIP
}

This paper aims to present the social cooperative movement in Poland's rural areas as illustrated by social cooperatives operating in rural communes of the Masovian Voivodeship. Of the 32 units operating at least since 2014, only 10 have remained on the market. Based on the National Court Register data, the study examined activity profiles, employment levels, activity periods, founding entities and financial situations by using the method of indicators of dynamics and return on sales (ROS). Cooperatives were selected with regard to the legal nature of their founders in order to indicate any differences. The cooperatives established by legal persons had a stable financial situation in the case of $80 \%$ of the analysed entities. All of them recorded an increase in revenues in comparison to the year before and $80 \%$ of them reported a profit and a positive ROS. $80 \%$ of the entities established by natural persons generated a loss from conducted activities and a negative ROS in the last three years of conducted activities. The research results showed that the greatest chances for development were found in cooperatives that were established by legal persons and which rendered services of general interest.

Key words: social cooperatives, rural areas, Masovian Voivodeship

JEL Codes: D 69, R 11

\section{Introduction}

Over the past few decades, in many European countries social enterprises have been developing at a very dynamic pace, more quickly than other economic sectors ${ }^{1}$. An example of such enterprises operating in Poland can be found in the social cooperatives that perform a key role in the social economy. They currently constitute the most common and most frequently used tool to stimulate business activity in the social economy. Since 2006, the Act on Social Cooperatives has been in force ${ }^{2}$. It has been amended many times to incorporate suggestions of cooperative members and the institutions that support them. The most important changes concern the ability to establish cooperatives by legal persons (since 2009), a reduction in the number of persons entitled to establish such entities, and a reduction in the percentage requirements for persons at risk of social exclusion. Despite the above-mentioned facilitations, the number of established entities is still not high. In addition, the entities already operating

\footnotetext{
${ }^{1}$ Borzaga C., Salvatori G., Bodini R..: Social and solidarity economy and the future of work, ed. International Labour Office, Geneva, 2017, p. 4.

${ }^{2}$ Journal of Laws of 2006, no. 94, item 651, as amended
} 
on the market face formal and legal challenges, as well as economic issues and problems connected with interpersonal relations ${ }^{3}$.

The presence of social economy entities in rural areas is of particular significance. Social entrepreneurship can affect the growth of entrepreneurship in general, and support sustainable models of business development in rural areas by helping to satisfy the needs of rural communities ${ }^{4}$. However, social cooperatives in rural areas are still an underutilized tool for assisting socially and economically marginalized persons with full reintegration into the labour market ${ }^{5}$.

Effective collaboration constitutes the foundation on which the social economy is based. In particular, collaboration for people who have gone into a difficult material standing and who are unable to find their footing in their current surroundings. Cooperation with third parties who are ready to help (not only financially) may provide them with versatile advantages. There are many situations like this in rural areas and they result from various reasons, such as the specificity of agricultural activities ${ }^{6}$.

\section{Theoretical basis}

The EMES (European Research Network) presents the social enterprise as one whose activities are oriented towards social purposes and whose gains do not serve the maximisation or increase in profit of partners or owners, but are applied for statutory objectives or invested in the community itself. According to the EMES, these entities should meet the below-mentioned social and economic criteria:

Table 1. Criteria distinguishing social enterprises according to the EMES network

\begin{tabular}{|l|l|}
\hline \multicolumn{1}{|c|}{ Economic criteria } & \multicolumn{1}{|c|}{ Social criteria } \\
\hline $\begin{array}{l}\text { conducting relatively continuous and regular } \\
\text { activity based on economic instruments; }\end{array}$ & $\begin{array}{l}\text { clear orientation towards a socially useful project } \\
\text { purpose; }\end{array}$ \\
\hline $\begin{array}{l}\text { autonomy, sovereignty of institutions against public } \\
\text { institutions; }\end{array}$ & grassroots, civic nature of the initiative; \\
\hline economic risk bearing; & $\begin{array}{l}\text { specific, possibly democratic system of } \\
\text { management; }\end{array}$ \\
\hline existence of even low-waged personnel; & possibly community nature of operation; \\
\hline & limited profit distribution; \\
\hline
\end{tabular}

Source: Polski model ekonomii społecznej ...2008 ${ }^{7}$.

This definition shows that the sense of social economy is multi-dimensional. Business activity allows for the accomplishment of social and professional re-integration - mainly due to the employment of persons at risk of exclusion - and of other social objectives, such as provision of services satisfying socially significant needs (e.g. guardianship,

${ }^{3}$ Determinanty przeżywalności spółdzielni socjalnych w woj. mazowieckim. Raport z badania, wyd. Mazowieckie Centrum Polityki Społecznej, Warszawa-Cieszyn 2018, s. 5.

${ }^{4}$ Yonous Jami M., Gokdeniz I.: Rural development through social entrepreneurship, Rocznik Administracji Publicznej wyd. 4, Kraków 2018, s. 238.

${ }^{5}$ Krzyminiewska G.: Promotion of human capital of the rural population in the development process of selected social economy operators, Journal of Agribusiness and Rural Development nr 2 (44), 2017, p. 377-382.

${ }^{6}$ Parzonko A.. : Ekonomia społeczna a obszary wiejskie - stan i przewidywane kierunki zmian [in:] Ekonomia społeczna między rynkiem, państwem a obywatelem, ed. Murzyn D. and Pach J., wyd. Difin, Warszawa 2018, s. 316. ${ }^{7}$ Polski model ekonomii społecznej. Rekomendacje dla rozwoju, red. P. Frączek i .J. Wygnański, wyd. Fundacja Inicjatyw Społeczno-Ekonomicznych, 2008, Warszawa, s.19. 
social needs) or use of profits from business activity for socially useful purposes (see: Defourny, J., Hulgård, L. i Pestoff, V ${ }^{8}$, Batko, Bogacz-Wojtanowska ${ }^{9}$; Zboronn ${ }^{10}$; Schimanek ${ }^{11} ;$ Krzyminiewska $^{12}$ ). Social cooperatives are business entities that combine the features of an enterprise and a non-governmental organisation. The cooperative's main purpose is to provide its members with work. A social cooperative may be established by persons belonging to excluded social groups or groups at risk of social exclusion who are strictly defined in the Act (unemployed, homeless, addicted, mentally ill, released from prison or people with disabilities) and by at least two legal persons, such as: non-governmental organisations, local governmental bodies or church legal persons.

Pursuant to the law, a cooperative must be established by at least three natural persons (ultimately at least five persons), but not more than 50. The cooperative members may also include persons not mentioned in the Act, who are named 'specialist' in the Act, but their number may not exceed $50 \%$ of all organisation members. Social enterprises are subject to the same market demands as every entity conducting business activity. However, they do not distribute profit or balance surplus among each other, but they dedicate it to strengthening their potential, professional and social re-integration or activities of general interest for the benefit of local community. Therefore, they must be competitive and well-managed.

The basic issue related to the functioning of social economy entities (SEEs) is their financing. Apart from revenues from their paid activities, social economy entities may use various funding sources. Two main financing forms should be distinguished, i.e. non-returnable and returnable financial instruments. Among the instruments previously offered to social economy entities, there are, as follows:

1) Funding sources for non-investment projects in the form of non-repayable grants, e.g. Operational Programme 'Human Resources Development' (PO KL), Operational Programme 'Civic Initiative Fund' (PO FIO), Swiss Financial Mechanism, European Social Fund (EFS), and European Regional Development Fund (ERDF).

2) Funding sources for investment projects in the form of non-returnable instruments, e.g. Rural Development Programme (RDP), PO KL, ESF, and ERDF.

3) Public funds available for social economy entities, e.g. State Fund for Rehabilitation of Disabled People, Labour Fund, bank credit or loan from special funds.

4) Public administration budgets as funding sources for social economy entities, e.g. provisions of the Act of 24 April 2003 on public benefit activity and volunteerism ${ }^{13}$ and contracts for services with public administration, so-called social clauses.

\footnotetext{
${ }^{8}$ Defourny, J., Hulgård, L. i Pestoff, V., Social enterprise and the third sector. Changing European landscapes in a comparative perspective. 2014, New York: Routledge.

${ }^{9}$ Batko R., Bogacz-Wojtanowska E.: Przedsiębiorstwa społeczne - poszukiwanie tożsamości pomiędzy celami ekonomicznymi a społecznymi, Problemy Zarządzania, vol. 13, wyd. 4, 2015, s. 195-206.

${ }^{10}$ Zboroń H.. : Social economics - from the profit oriented market to the social entrepreneurship, in: RojekNowosielska M. (ed.), Social Responsibility of Organizations. Directions of Changes, Prace Naukowe Uniwersytetu Ekonomicznego (AE) we Wrocławiu, 387, 2015, Wrocław.

${ }^{11}$ Schimanek T.: Finansowanie przedsiębiorstw społecznych w Polsce, Ekonomia Społeczna, wyd. 2, 2015, Kraków.

${ }^{12}$ Krzyminiewska G.,op.cit.,pp.377-382.

${ }^{13}$ Journal of Laws of 2003 No. 69, item 873, as amended
} 
5) Fundraising sources for social economy entities, e.g. $1 \%$ of tax, grants, donation, sponsorship, paid activity, public collection.

Cooperatives actively use various forms of support and they have also used returnable instruments, but their largest obstacle is often a lack of funds for repaying those forms of returnable support ${ }^{14}$.

\section{Research material and methodology}

This paper aims to present the functioning of the social cooperative movement in rural areas as illustrated by ten social cooperatives operating in Poland's Masovian Voivodeship. Rural areas shall mean rural and urban-rural communes. Detailed data concerning founders, activity profile, year of establishment, number of employees and financial situation of particular entities were obtained from the National Court Register. Documents that helped determine the economic situation of cooperatives included their valid financial statements, balance sheets, profit and loss accounts, and reports on activities. A factor in selecting cooperatives for research was the submission of a financial statement and presence on the market since at least 2014, i.e. for at least five years. According to the Polish Catalogue of Social Cooperatives ${ }^{15}, 145$ social cooperatives were operating in the Masovian Voivodeship of 31 May 2018. In 2014, 108 social cooperatives were registered (status as of 31 December 2014), including $29 \%$ in rural areas. $31 \%$ from among 32 social cooperatives figuring in the National Court Register, i.e. ten entities, are still operating and active. This is much less than the national average. In Poland, less than two-thirds of 1.4 thousand social cooperatives registered at the end of 2016 have been active ( 0.9 thousand $)^{16}$. Many cooperatives have already been liquidated or have ended their activities. They were established thanks to EU financial support and upon the completion of that support, they ended their activities. However, due to an expensive and complicated process of inspection, they are still registered in the National Court Register, thus inducing error as to the actual number of existing enterprises.

The fact that the majority of social economy entities operate in urban communes, mainly in Warsaw, should also be considered. Through selection, data concerning five cooperatives established by natural persons and five entities established by legal persons were collected. Cooperatives were selected with regard to the legal nature of their founders in order to indicate any differences. The collected data were also analysed with use of indicators of dynamics (previous year $=100$ ), taking into consideration revenues obtained in the last three years - 2016, 2017, and 2018. As the examined social cooperatives perform mainly service activities, ROS was also researched $=$ net profit/sales revenues x $100 \%$. The focus was on the research of economic condition that might constitute a determinant of stability. In the case of a poor economic condition, the cooperative is de facto unable to accomplish social objectives, as it does not have any funds for this, or to perform its functions related to re-integration. In the case of a satisfying economic condition (when the cooperative is able to balance its business

\footnotetext{
${ }^{14}$ Raport końcowy. System wsparcia finansowego dla ekonomii społecznej na Mazowszu, 2014: ASM-

Centrum Badań i Analiz Rynku sp. z o.o. Kutno, s.56.

${ }^{15}$ www.spoldzielniesocjalne.org

${ }^{16}$ Social cooperatives in 2016. Advance information of the CSO as of 21 February 2018, p. 2.
} 
activity, achieving zero profit), it may perform its functions related to re-integration, but it does not have any funds for statutory objectives. In turn, when the condition is good, the cooperative both performs its functions and accomplishes social purposes ${ }^{17}$.

\section{Results and discussion}

While operating on the competitive market and being subject to the same principles as competitive entities, the social cooperative must obtain and maintain commissioners, guarantee itself profits and keep financial liquidity. This is a difficult challenge for excluded persons who have not conducted business activity before. Based on the example of cooperatives operating in the rural areas of the Masovian Voivodeship, it might be stated that 13 cooperatives, i.e. $40 \%$, were functioning only for the project duration, i.e. up to two years. Six entities have been operating for more than two years, including $67 \%$ functioning for three years.

Table 2. Duration of social cooperatives in the rural areas of the Masovian Voivodeship

\begin{tabular}{|c|c|}
\hline $\begin{array}{l}\text { Cooperatives operating only for the project duration up to } \\
\text { two years }\end{array}$ & $\begin{array}{l}\text { Cooperatives operating for more than two } \\
\text { years }\end{array}$ \\
\hline $\begin{array}{l}\text { Opportunity Halinów (2005); You and Us Zwoleń (2007); } \\
\text { Gardens of Dreams Nowe Gulczewo (2008); Subrento } \\
\text { Raciąż (2010); Opportunity Zalesie Górne (2010); Together } \\
\text { Puszcza Mariańska (2012); Eco-Comfort Łosice (2013); } \\
\text { Emetus Brudzień Duży (2013); Forum Różan (2013); Pierot } \\
\& \text { Rose (2013); Crochet Hoot the Dragon Szydłowiec } \\
\text { (2013); Janopole Social Cooperative Janopole (2013); } \\
\text { Domino Opinogóra Górna (2014); Locomotive Czernice } \\
\text { Borowe (2014) }\end{array}$ & $\begin{array}{l}\text { Care Słupno (2007-2017); Karina } \\
\text { Suchożebry (2012-2015); } \\
\text { Wyszogrodzianka Wyszogród (2012- } \\
\text { 2017); Funpark Zaździerz (2014-2017); } \\
\text { Haven Władysławowo (2014-2017); } \\
\text { Cooperation Drobin (2014-2017); }\end{array}$ \\
\hline
\end{tabular}

Source: author's own development based on the National Court Register data.

The above situation is specific not only to the Masovian Voivodeship. According to the Information on the Operation of Social Cooperatives in $2016-2017^{18}$, six in ten cooperatives established between 2012 and 2015 declared significant difficulties in the conducted activity, while $15 \%$ considered the end of their activity in 2017 due to the problems encountered. Common barriers concerned financial matters, such as high nonwage employment costs (44\%), insufficient financial means $(41 \%)$, and heavy budgetary burden $(32 \%)$. Some social cooperatives also noticed obstacles related to the entity's market position, in particular to too strong competition (40\%). Difficulties related to unclear, incoherent and unstable legal regulations (31\%), as well as to insufficient funds at the disposal of customers $(27 \%)$ were also quite common.

\section{Cooperatives established by natural persons}

As Table 3 shows, all cooperatives established by natural persons perform mainly service activities. Two Masovian cooperatives, Ant and Faktoria, perform cleaning services (26\%). The Shine cooperative renders care services, Our Folks runs a restaurant,

\footnotetext{
${ }^{17}$ Czetwertyński S.: Znaczenie i kondycja ekonomiczna polskich spółdzielni socjalnych, Społeczeństwo i ekonomia, 1(7), 2017, Wrocław, s. 52.

${ }^{18}$ Information on functioning of social cooperatives operating pursuant to the Act of 27 April 2006 on social cooperatives for 2016-2017: document of the Council of Ministers no. 24/158/18, 2018, Warsaw.
} 
while Green Needle is occupied with stray production and sewing services. Three entities do not have additional employees.

Table 3. Social cooperatives of natural persons

\begin{tabular}{|l|c|l|c|}
\hline \multicolumn{1}{|c|}{$\begin{array}{c}\text { Name and area of } \\
\text { activities }\end{array}$} & $\begin{array}{c}\text { Year of } \\
\text { establishment }\end{array}$ & \multicolumn{1}{|c|}{ Main activity profile } & $\begin{array}{c}\text { Number of } \\
\text { employees }\end{array}$ \\
\hline Ant Łosice & 2010 & cleaning services & 5 \\
\hline Shine Platerów & 2011 & care services & 5 \\
\hline Faktoria Zielonka & 2012 & cleaning and recreational services & 8 \\
\hline Green Needle Jeziorno & 2013 & sewing services and stray production & 5 \\
\hline Our Folks Chodów & 2014 & food services & 6 \\
\hline
\end{tabular}

Source: author's own development based on the National Court Register data.

The cooperative members are also employees hired on the basis of a cooperative contract of employment, while their wages constitute the entity's deductible expense. As the examined entities perform only services, the amount of their revenues reflects their financial situation allowing to define the enterprise's activity, therefore it constitutes a reference point for the assessment of profit level and resource involvement.

Table 4. Financial data for cooperatives of natural persons

\begin{tabular}{|c|c|c|c|c|c|c|c|}
\hline Name & $\begin{array}{l}\text { Revenues } \\
\text { and profit } \\
\text { in } 2016 \text { [in } \\
\text { thousand } \\
\text { PLN] }\end{array}$ & $\begin{array}{l}\text { Revenues } \\
\text { and profit } \\
\text { in } 2017 \text { [in } \\
\text { thousand } \\
\text { PLN] }\end{array}$ & $\begin{array}{l}\text { Revenues } \\
\text { and profit } \\
\text { in } 2018 \text { [in } \\
\text { thousand } \\
\text { PLN] }\end{array}$ & $\begin{array}{l}\text { Dynamics of } \\
\text { revenues in } \\
2017 \\
{[2016=100]}\end{array}$ & $\begin{array}{l}\text { Dynamics of } \\
\text { revenues in } \\
2018 \\
{[2017=100]}\end{array}$ & $\begin{array}{l}\text { ROS } \\
\text { in } \\
2017 \\
\text { [in \%] }\end{array}$ & $\begin{array}{l}\text { ROS in } \\
2018 \\
{[\text { in } \%]}\end{array}$ \\
\hline Ant & $\begin{array}{r}88.37 \\
0.01\end{array}$ & $\begin{array}{c}96.90 \\
0.13\end{array}$ & $\begin{array}{c}102.13 \\
4.20\end{array}$ & 109.65 & 105.39 & 0.13 & 4.11 \\
\hline Shine & $\begin{array}{l}65.42 \\
-9.93\end{array}$ & $\begin{array}{r}58.40 \\
-15.89\end{array}$ & $\begin{array}{l}109.15 \\
-38.74\end{array}$ & 89.27 & 186.90 & -27.20 & -35.49 \\
\hline Faktoria & $\begin{array}{l}45.43 \\
-0.56\end{array}$ & $\begin{array}{l}55.31 \\
-2.97 \\
\end{array}$ & $\begin{array}{l}86.95 \\
-3.76 \\
\end{array}$ & 121.75 & 157.20 & -5.37 & -4.32 \\
\hline $\begin{array}{l}\text { Green } \\
\text { Needle }\end{array}$ & $\begin{array}{c}27.75 \\
-15.23\end{array}$ & $\begin{array}{l}22.03 \\
-4.33\end{array}$ & $\begin{array}{c}21.36 \\
-10.93\end{array}$ & 79.38 & 96.96 & -19.65 & -51.17 \\
\hline $\begin{array}{l}\text { Our } \\
\text { Folks }\end{array}$ & $\begin{array}{l}256.15 \\
-15.76\end{array}$ & $\begin{array}{c}222.41 \\
6.31\end{array}$ & no data & 86.83 & no data & 2.83 & no data \\
\hline
\end{tabular}

Source: author's own development based on data from financial statements in the National Court Register data.

The research results indicate that the Ant cooperative from Losice is in the best financial situation, as it has been the only one to report a profit in the last three years, which came in 2018 to PLN 4.20 thousand. Its revenues grow year by year at a steady rate. In addition, it is the only one to have a positive ROS in two subsequent years, which came to $4.11 \%$ in 2018 . The Faktoria cooperative, despite recording an increase in revenues, still has not achieved a profit or positive ROS after seven years of activity. The Shine cooperative achieved the largest increase in revenues in 2018 - by $86.90 \%$, but its return on sales is still very low: $-27.20 \%$ in 2017 and $-35.49 \%$ in 2018 . In 2018 , that entity incurred operating loss coming to PLN 38.74. The increase in revenues in the Faktoria and Shine cooperative allowed for an increase in wages and investments, which resulted in an increase in losses, but was done to improve motivation. In 2017, the Our Folks cooperative had ROS coming to $2.83 \%$, but it showed also decrease in revenues and probably suspended its activities, as there were no financial data for 2018 . The 
Green Needle has the poorest financial situation, as it generates very low revenues, which, in addition, are falling year by year.

The above analysis shows that there is a question mark over further operation of two cooperatives - Our Folks and Green Needle. An unfavourable financial situation is a typical phenomenon for the majority of social economy entities. According to the CSO data $^{19}$, in 2016, 39\% of social cooperatives generated revenues covering the costs incurred (i.e. a zero profit was achieved), $37 \%$ sustained a loss, while only $24 \%$ had a surplus of revenues over costs, i.e. positive financial result. Business activity constitutes only an additional source of funding of their operations. Public funds prevail (EU funds, state special-purpose assets, local governments), which raise concerns about the stability of such entities after the cessation of EU support ${ }^{20}$. It should also be emphasised that social enterprises employ disabled and socially excluded persons, thus having lower labour productivity and higher costs of products and services, which is why they use public aid, which contributes to self-sufficiency or profit making ${ }^{21}$. A lack of product orders is the primary reason for a poor financial situation in the majority of examined cases.

\section{Cooperatives established by legal persons}

The Perspective cooperative, established in 2012 by two associations at the Youth Detention Centre in Studzieniec, is the longest-lasting cooperative. The entity has as many as 47 employees. Under agreements, all of the Centre's youths undergo practical occupational education through the entity.

Table 5. Social cooperatives established by legal persons

\begin{tabular}{|c|c|c|c|c|}
\hline $\begin{array}{l}\text { Name and } \\
\text { location }\end{array}$ & $\begin{array}{c}\text { Year of } \\
\text { establishment }\end{array}$ & Activity profile & Founders & $\begin{array}{l}\text { Number of } \\
\text { employees }\end{array}$ \\
\hline $\begin{array}{l}\text { Perspective at the } \\
\text { Youth Detention } \\
\text { Centre in } \\
\text { Studzieniec }\end{array}$ & 2012 & $\begin{array}{l}\text { food, cleaning } \\
\text { services and } \\
\text { maintenance of green } \\
\text { areas }\end{array}$ & $\begin{array}{l}\text { Association for the Youth } \\
\text { Detention Centre Support } \\
\text { OSADA and Association } \\
\text { Start } 9\end{array}$ & 47 \\
\hline $\begin{array}{l}\text { Centre for } \\
\text { Environmental } \\
\text { Services Słupno }\end{array}$ & 2012 & $\begin{array}{l}\text { municipal and care } \\
\text { services }\end{array}$ & $\begin{array}{l}\text { Słupno commune, } \\
\text { Bolkowo, Mała Wieś; the } \\
\text { parish of Saint Martin and } \\
\text { association from Płock }\end{array}$ & 30 \\
\hline Oasis Klwów & 2013 & $\begin{array}{l}\text { tourist } \\
\text { accommodation } \\
\text { services }\end{array}$ & $\begin{array}{l}\text { Klwów commune and } \\
\text { Association Common } \\
\text { Dream }\end{array}$ & 8 \\
\hline $\begin{array}{l}\text { Węgrowianka } \\
\text { Węgrów }\end{array}$ & 2014 & $\begin{array}{l}\text { cleaning and } \\
\text { municipal services }\end{array}$ & $\begin{array}{l}\text { Węgrów commune and } \\
\text { Poviat Starost's Office in } \\
\text { Węgrów }\end{array}$ & 7 \\
\hline Reduar Alojzów & 2014 & $\begin{array}{l}\text { care services, } \\
\text { rehabilitation and arts } \\
\text { workshop }\end{array}$ & $\begin{array}{l}\text { Association for } \\
\text { Development of Alojzów } \\
\text { Village and its Region and } \\
\text { Father Pio Association in } \\
\text { Radom }\end{array}$ & 7 \\
\hline
\end{tabular}

Source: author's own development based on the National Court Register data.

${ }^{19}$ Social cooperatives in 2016 , op. cit.

${ }^{20}$ Schimanek T., 2015 op. cit. s. 15.

${ }^{21}$ Górka K., Łuszczyk M., Thier A.: Ekonomia społeczna jako wyzwanie dla współczesnych przedsiębiorstw [w:] Przedsiębiorczość społeczna-innowacje-środowisko, ed. Pach J., Śliwa R., Maciejewski W., 2019 wyd. CeDeWu, Warszawa s. 231. 
Also in 2012, the Social Cooperative of Legal Persons Centre for Environmental Services (CES) was established. Its founders include the Słupno commune, Bolkowo, Mała Wieś, the parish of Saint Martin in Słupno and the Association for Innovation of Information Society in Płock. In 2017, the cooperative was joined by the Radzanowo commune, Drobin town and commune, and the Association Practice and Innovation Academy in Płock. Its main activity is formed by the municipal services for associated communes, but CES also runs the Occupational Therapy Workshops in Mirosław for 30 persons, Daily Senior Residence Vigour in Drobin and a shelter for homeless dogs in Mała Wieś, having a total of 30 employees. The long-term unemployed or persons under the municipal social welfare centre's care constitute almost $70 \%$ of its employees.

The Oasis cooperative rendering tourist accommodation services has at its disposal 17 rooms and a banqueting hall. It was established on an initiative of the Klwów commune and the Common Dream Association. This organisation conducts Occupational Workshops rendering catering services for hotel guests and event participants.

Established in 2014 by two associations, the Reduar cooperative providing rehabilitation, art workshops and care services employs persons qualified in their specialties: four physiotherapists, one pedagogue, one artist and one decoupage instructor.

The financial situation of entities established by legal persons is much better than that of cooperatives established by natural persons, as Table 6 shows. Special attention should be paid to the Centre for Environmental Services, which experienced an increase in revenues by $350 \%$ in 2019 against the year before. The rapid increase in revenues was caused by the expansion of activities by new municipalities and new orders. As a result, the costs related to the employment of new employees and the purchase of fixed assets increased. The cooperative does not suffer loss from conducted activity, while achieving every year a profit at the level of several thousand zloty (in 2016 - PLN 18.19 thousand; in 2017 - PLN 14.69 thousand, and in 2018 - PLN 12.48 thousand) and having a positive ROS.

Table 6. Financial data for cooperatives of legal persons

\begin{tabular}{|c|c|c|c|c|c|c|c|}
\hline $\begin{array}{l}\text { Name of social } \\
\text { cooperative }\end{array}$ & $\begin{array}{l}\text { Revenues } \\
\text { and profit } \\
\text { in } 2016 \text { [in } \\
\text { thousand } \\
\text { PLN] }\end{array}$ & $\begin{array}{c}\text { Revenues } \\
\text { and profit } \\
\text { in } 2017 \text { [in } \\
\text { thousand } \\
\text { PLN] }\end{array}$ & $\begin{array}{l}\text { Revenues } \\
\text { and profit } \\
\text { in } 2018 \text { [in } \\
\text { thousand } \\
\text { PLN] }\end{array}$ & $\begin{array}{c}\text { Dynamics } \\
\text { of } \\
\text { revenues } \\
\text { in } 2017 \\
{[2016=10} \\
0]\end{array}$ & $\begin{array}{c}\text { Dynamic } \\
\text { s of } \\
\text { revenues } \\
\text { in } 2018 \\
{[2017=1} \\
00]\end{array}$ & $\begin{array}{l}\text { ROS } \\
\text { in } \\
2017 \\
\text { [in \%] }\end{array}$ & $\begin{array}{l}\text { ROS } \\
\text { in } \\
2018 \\
\text { [in \%] }\end{array}$ \\
\hline Perspective & $\begin{array}{r}25.36 \\
-1.38 \\
\end{array}$ & $\begin{array}{c}30.84 \\
1.68 \\
\end{array}$ & $\begin{array}{c}31.02 \\
1.87 \\
\end{array}$ & 121.60 & 100.58 & 5.45 & 6.02 \\
\hline $\begin{array}{l}\text { Centre for } \\
\text { Environmental } \\
\text { Services }\end{array}$ & $\begin{array}{c}402.56 \\
18.19\end{array}$ & $\begin{array}{c}355.59 \\
14.69\end{array}$ & $\begin{array}{c}1,247.66 \\
12.48\end{array}$ & 88.33 & 350.87 & 4.13 & 1.00 \\
\hline Wegrowianka & $\begin{array}{r}234.17 \\
-28.66 \\
\end{array}$ & $\begin{array}{l}284.03 \\
-21.57 \\
\end{array}$ & $\begin{array}{l}201.33 \\
-64.73 \\
\end{array}$ & 121.29 & 70.88 & -7.59 & -32.15 \\
\hline Oasis & $\begin{array}{l}70.30 \\
-0.52 \\
\end{array}$ & $\begin{array}{l}88.84 \\
29.97 \\
\end{array}$ & $\begin{array}{r}56.16 \\
-17.48 \\
\end{array}$ & 126.37 & 63.21 & 33.73 & -31.12 \\
\hline Reduar & $\begin{array}{l}39.75 \\
-9.90\end{array}$ & $\begin{array}{l}32.43 \\
-0.95\end{array}$ & $\begin{array}{r}53.59 \\
3.57\end{array}$ & 81.58 & 165.25 & -2.92 & 6.66 \\
\hline
\end{tabular}

Source: author's own development based on data from financial statements in the National Court Register data. 
In the last three years, the Perspective cooperative generated increasing revenues and profit, as well as ROS at the level of $5.45 \%$ in 2017 and $6.02 \%$ in 2018. Also the Reduar cooperative reported increasing revenues, profit, and ROS at the level of $6.66 \%$ in 2018., The Oasis cooperative, established in 2013, did not have any financial problems in 2016 and 2017. Revenues were reduced by 36\%, with losses coming to PLN 17.48 and ROS at the level of $-31.12 \%$, occurred only in 2018. Pursuant to the report, that situation was only temporary and related to a hotel renovation. The Wegrowianka cooperative has the most difficult financial situation. As its report on activities showed, it had been established by two local governments, i.e. the Municipal Office in Wegrów and the Poviat Starost's Office in Wegrów, to be able to perform their ordered tasks. Unfortunately, the situation changed and a call for tender was launched for orders that the cooperative had performed so far and could continue. It lost the tender with a competitive company from outside the commune. Therefore, Wegrowianka had to look for orders on its own and had to extend the scope of its activities by repair and construction services, as well as care and cleaning services for senior citizens. However, the funds obtained from service performance are not enough to keep the cooperative up and its position is at risk. Further functioning of the cooperative depends largely on the favour of local governmental bodies, as pursuant to the statutory provisions they enact the entity's direction of development for the upcoming years. This condition is confirmed by the fact that responsibility for development of local communities - despite an assumption that it shall be divided among all stakeholders: public, private and social sector - is still borne mainly by local governmental bodies ${ }^{22}$ constituting prime movers of these entities.

\section{Summary}

Only one in three $(31 \%)$ social cooperatives established in rural areas in Poland's Masovian Voivodeship has been actively functioning on the market for at least five years. The financial situation of entities established by legal persons is much better than for entities established by natural persons. Most of them (80\%) recorded an increase in revenues compared to the year before and $66 \%$ recorded a profit and a positive ROS. They perform their role very well by fulfilling re-integration and statutory services, having also many employees. The Centre for Environmental Services cooperative deserves special recognition, as it has generated the highest revenues and financial results. Cooperatives established by natural persons encounter a completely different situation, as $80 \%$ of them have generated a loss from conducted activities and a negative ROS in the last three years of conducted activities. As many as $60 \%$ of cooperatives collected low revenues - below PLN 100 thousand. The same number do not have additional employees. The financial situation of two organisations is particularly poor and they are at risk of insolvency. Activities of cooperatives in the rural areas of the Masovian Voivodeship are diverse. Frequent activity profiles were cleaning services $(50 \%)$, maintenance of green areas $(40 \%)$, care services $(30 \%)$, and food services $(20 \%)$.

\footnotetext{
${ }^{22}$ Kołomycew A., Pawłowska A..: Partnerstwa międzysektorowe w rozwoju obszarów wiejskich na przykładzie Lokalnych Grup Działania w województwie podkarpackim, Studia Regionalne i Lokalne, 2(52), 2013 s. 76.
} 
Based on the above analysis, it may be stated that a significant impact on social and economic development of rural areas may be exercised mainly by social enterprises established by legal entities and rendering services of general interest for the benefit of local governmental bodies and local community.

\section{Literature}

Act of 24 April 2003 on public benefit activity and volunteerism (Journal of Laws of 2003 No. 69, item 873 , as amended).

Act of 27 April 2006 on social cooperatives (Journal of Laws of 2006 No. 94, item 651, as amended).

Batko R., Bogacz-Wojtanowska E.: 2015: Przedsiębiorstwa społeczne - poszukiwanie tożsamości pomiędzy celami ekonomicznymi a społecznymi, Problemy Zarządzania, vol. 13, issue 4, 2015 s. 195-206.

Borzaga C., Salvatori G., Bodini R..: Social and solidarity economy and the future of work, ed. International Labour Office, Geneva, 2017.

Czetwertyński S.: Znaczenie i kondycja ekonomiczna polskich spółdzielni socjalnych, Społeczeństwo i ekonomia, 1(7), Wrocław, 2017,s. 46-60.

Defourny, J., Hulgård, L. i Pestoff, V.: Social enterprise and the third sector. Changing Europe-an landscapes in a comparative perspective. New York: Routledge, 2014.

Determinanty przeżywalności spółdzielni socjalnych w woj. mazowieckim. Raport z badania 2018, wyd. Mazowieckie Centrum Polityki Społecznej, Warszawa-Cieszyn, 2018.

Górka K., Łuszczyk M., Thier A., 2019: Ekonomia społeczna jako wyzwanie dla współczesnych przedsiębiorstw [w:] Przedsiębiorczość społeczna-innowacje-środowisko, red. Pach J., Śliwa R., Maciejewski W., wyd. CeDeWu, Warszawa, 2019.

Information on functioning of social cooperatives operating pursuant to the Act of 27 April 2006 on social cooperatives for 2016-2017: document of the Council of Ministers no. 24/158/18, Warsaw, 2018.

Kołomycew A., Pawłowska A.: Partnerstwa międzysektorowe w rozwoju obszarów wiejskich na przykładzie Lokalnych Grup Działania w województwie podkarpackim, Studia Regionalne i Lokalne, 2(52), 2013.

Krzyminiewska G.: Promotion of human capital of the rural population in the development process of selected social economy operators, Journal of Agribusiness and Rural Development nr 2 (44), 2017, p. 377-382.

Parzonko A.: Ekonomia społeczna a obszary wiejskie - stan i przewidywane kierunki zmian [w:] Ekonomia społeczna między rynkiem, państwem a obywatelem, red. Murzyn D. i Pach J., wyd. Difin, Warszawa, 2018.

Polish Catalogue of Social Cooperatives (www.spoldzielniesocjalne.org).

Polski model ekonomii społecznej. Rekomendacje dla rozwoju, red. Frączek P. i Wygnański J., wyd. Fundacja Inicjatyw Społeczno- Ekonomicznych, Warszawa, 2008.

Raport końcowy. System wsparcia finansowego dla ekonomii społecznej na Mazowszu, wyd. ASM- Centrum Badań i Analiz Rynku sp. z o.o. Kutno, 2014.

Schimanek T.: Finansowanie przedsiębiorstw społecznych w Polsce, Ekonomia Społeczna, 2, Kraków, 2015.

Social cooperatives in 2016. Advance information of the CSO as of 21 February 2018.

Yonous Jami M., Gokdeniz I.: Rural development through social entrepreneurship, Rocznik Administracji Publicznej issue 4, Kraków, 2018.

Zboron H.: Social economics - from the profit oriented market to the social entrepreneurship, in: Rojek-Nowosielska M. (ed.), Social Responsibility of Organizations. Directions of Changes, Prace Naukowe Uniwersytetu Ekonomicznego (AE) we Wrocławiu, 387, Wrocław, 2015. 


\section{Funkcjonowanie przedsiębiorczości społecznej na obszarach wiejskich na przykładzie spółdzielni socjalnych województwa mazowieckiego}

\section{Streszczenie}

Celem artykułu jest przedstawienie przedsiębiorczości społecznej na obszarach wiejskich na przykładzie spółdzielni socjalnych mających siedzibę w gminach wiejskich woj. mazowieckiego. Ustalono, że spośród 32 jednostek funkcjonujących co najmniej od 2014 roku, na rynku utrzymało się tylko 10. Na podstawie danych z KRS zbadano profil działalności, poziom zatrudnienia, okres prowadzenia działalności, podmioty założycielskie oraz sytuację finansową przy wykorzystaniu metody indeksów dynamiki oraz wskaźnika rentowności sprzedaży (ROS). Wyodrębniono spółdzielnie pod względem podmiotowości prawnej założycieli, celem wskazania różnic. Wśród podmiotów założonych przez osoby prawne występuje stabilna sytuacja finansowa dla $80 \%$ analizowanych jednostek. We wszystkich z nich nastąpił wzrost przychodów w porównaniu do roku ubiegłego a $80 \%$ z nich odnotowała zysk oraz dodatni ROS. Spośród spółdzielni założonych przez osoby fizyczne $80 \%$ wykazało stratę z prowadzonej działalności oraz ujemny ROS w trzech ostatnich latach prowadzonej działalności. Wyniki badań wykazały, że największe szanse na rozwój mają spółdzielnie socjalne założone przez osoby prawne i świadczące usługi użyteczności publicznej.

Słowa kluczowe: spółdzielnie socjalne, obszary wiejskie, woj. Mazowieckie JEL Codes: D 69, R 11

\section{Information about the author:}

Małgorzata Błażejowska, PhD

Koszalin University of Technology,

Faculty of Economic Sciences

ul. Kwiatkowskiego 6B, 75-343 Koszalin, Poland

e-mail: blazejowska@op.pl

ORCID: 0000-0002-3279-9879 